\title{
Investigation of Health Sciences University Students' Healthy Living Behavior Perceptions
}

\author{
Nedim Malkoc ${ }^{1, *} \&$ Serap Çolak ${ }^{2}$ \\ ${ }^{1}$ Hamidiye Life Sciences Faculty, Health Sciences University, Istanbul, Turkey \\ ${ }^{2}$ Faculty of Sport Sciences, Kocaeli University, Kocaeli, Turkey
}

*Correspondence: Hamidiye Life Sciences Faculty, Health Sciences University, Istanbul, Turkey. Tel:90-541-455-3988. E-mail: drmalkocnedim@gmail.com

Received: May 20, 2020

doi:10.5430/wje.v10n4p124
Accepted: July 23, 2020 Online Published: August 22, 2020

URL: https://doi.org/10.5430/wje.v10n4p124

\begin{abstract}
All of the behaviors that people exhibit in order to stay healthy both physically and psychologically and maintain their health during their lifetime are included in the definition of "healthy life behavior". In this study, it was aimed to identify and compare the perceptions of healthy life behavior of students of the Department of Exercise and Sport Sciences and Psychology Department Students who study at the University of Health Sciences. A total of 199 students, 97 students from the sports science department (age: $19.84 \pm 1.801$, weight: $65.30 \pm 12.460$ ), and 102 students from the psychology department (age: $20.12 \pm 1.916$ weight: $60.17 \pm 9.881$ ) participated in the study. There was a statistically significant difference between the scale total scores of the participants and the dimensions of health responsibility, physical activity, nutrition, stress management, and the measurements of the students of sports science students and students of psychology sciences in terms of an increase in sport sciences students $(\mathrm{p}<0.05)$. There was no significant difference between the participants' interpersonal communication and spiritual development scores, which are the sub-dimensions of the scale $(\mathrm{p}>0.05)$. University education is an education period in which students can decide independently. These results showed that sports students and psychology sciences students' different undergraduate education also affected their healthy lifestyle behaviors. In this context, it is concluded that directing students of other departments of the university to exercise and sports activities will contribute to their perceptions of healthy lifestyle.
\end{abstract}

Keywords: healthy living behaviors, psychology, sports, students, university

\section{Introduction}

Health; It is defined as a complete physical, social and spiritual well-being of human by many health institutions, including the World Health Organization (Cakırcal1, 2000). In these days when the world goes through a pandemic process, the understanding of health; supports the health-centered and holistic care approach that protects, maintains and improves the health of the individual, family and communities (Duran et al., 2018, Sisk, 2000). People have important duties and responsibilities not only for themselves but also for protecting, maintaining and improving the health of society. All of the practices that protect people from physical, social and psychological diseases and ensure a healthy life are called "Healthy Lifestyle Practices" (Bahar et al., 2008). Healthy lifestyle is defined as controlling all the behaviors that affect the health of the individual and choosing the behaviors that are suitable for their health status in organizing their daily activities (Malkoç, 2019). During the university education, the students who study in different departments determine their life styles in this process mostly, the type, intensity and the status quo of the profession they will acquire. Healthy lifestyle behaviors include adequate and regular exercise, balanced nutrition, non-smoking, bad habits, stress management and hygienic measures (Malkoç, 2019). Active movements throughout the day play an important role in the maintenance and improvement of human health.

There are studies reporting that regular physical activity has a positive effect on various systemic functions (Sunay et al., 2020; Ayyıldız et al., 2019; Chrysohoou et al., 2015; Dimlioğlu \& Tekin, 2018; Conraads et al., 2015; Lim and Taylor, 2005). It has been found that regular sports or movement helps $10-30 \%$ improvement in the cardiovascular system of people, and also reduces risk factors, improves body composition, improves insulin resistance, and lowers 
blood pressure values of individuals with hypertension (Chrysohoou et al., 2015; Dimlioğlu and Tekin, 2018; Conraads et al., 2015; Lim and Taylor, 2005). Based on this, exercise and good wellness practices throughout the university life, which encompasses the intensive lesson and training process, will contribute to people's feeling better both physically and psychologically. In particular, the period when a person left his family perhaps for the first time and has the competence to make his own decisions outside his parents in terms of lifestyle (activity, hygiene, sleep patterns, nutrition, etc.) is the university student period (Yasar and Turgut, 2020). It is a fact that the department studied at the university has an effect on the lifestyles of the students. The lifestyle and the perceptions of Healthy Life Behavior may differ between the students of the Department of Exercise and Sports Sciences and the students of the Department of Psychology who have intensive theoretical course programs due to their efforts and lessons in terms of lifestyle and even healthy lifestyle. Every healthy life behavior performed during the university period will contribute to the protection of health, the continuation of the health system and the continuous improvement of health in the following years. Any kind of healthy life behavior (activity, hygiene, sleep patterns, nutrition, etc.) performed during this period will make people feel better and accordingly will affect the perception of Healthy Life Behavior. It is a known fact that one of the most important ways of protecting health in physical, emotional and psychological sense is sports (Turgut and Yasar, 2019). In order to get rid of all the negative conditions and keep the organism fit and healthy, it is necessary to reveal the need to do sports as a necessity (Zorba, 2015; Malkoc, 2019). In the research, it was aimed to compare the lifestyle and perceptions of Healthy Life Behaviors of the Department of Exercise and Sports Sciences Students who spend all their days compulsory with sports-related courses throughout the university life and the students of the Department of Psychology who do not participate in any compulsory sports activities with intensive theoretical course programs.

\section{Methods}

\subsection{Research Group}

The study was attended by 97 Exercise and Sports Sciences students and 102 psychology students, a total of 199 university students studying in the Faculty of Health Sciences.

\subsection{Data Collecting}

Quantitative research method was used in the study. In the research, the Healthy lifestyle behavior scale was applied by measuring the age and weight of the participants. In the study, the original Walker et al. (1987) and adapted to Turkish version Bahar et al. Healthy Lifestyle Behaviors Scale (52 items- 6 sub-dimensions) was used by. Health responsibility, physical activity, nutrition, interpersonal relationships, stress management and self-actualization (spiritual development) are the sub-dimensions of the scale. The total score obtained from this scale gives the overall healthy lifestyle behavior score. All items are scored positively. The scale is a 4-point Likert type, never (1), sometimes (2), often (3), regularly (4). The lowest score that can be obtained from the scale is 52 and the highest score is 208. Cronbach Alpha reliability coefficient of the scale is 0.94 . In our study, the overall Cronbach Alpha coefficient of the scale was calculated as 0.789 .

\subsection{Data Analysis}

Descriptive statistics calculations for the variables were made. Two independent samples $T$ test (Two Independent Samples T test) was used for variables that conform to normal distribution, and Mann Whitney U test, one of the nonparametric tests, was used for variables that did not conform to normal distribution. The data were analyzed with $5 \%$ margin of error in the $95 \%$ confidence interval. Information about the descriptive characteristics of the students is given in Table 1.

Table 1. Descriptive Statistics of the Age and Weight Variables of the Participants

\begin{tabular}{ccccccc}
\hline Groups & & $\mathrm{n}$ & Min. & Max. & $\overline{\mathrm{X}}$ & Standart Deviation \\
\hline \multirow{2}{*}{ Sports and Exerice Students } & Age & 97 & 18 & 28 & 19.84 & 1.80 \\
& Weight & 97 & 52 & 96 & 65.30 & 12.46 \\
\multirow{2}{*}{ Physigology Students } & Age & 102 & 18 & 30 & 20.12 & 1.91 \\
& Weight & 102 & 42 & 910 & 60.17 & 9.88 \\
\hline
\end{tabular}




\section{Results}

The averages and differences between the groups, which included the descriptive statistics and the healthy life behavior perception scale and sub-dimensions of the participants, are given in Table 2.

Table 2. Descriptive Statistics and P Values of the Scale Sub-dimensions and Total Scores of the Participant

\begin{tabular}{|c|c|c|c|c|c|c|c|c|}
\hline Sub-Dimensions & Groups & $\mathrm{n}$ & Min. & Mark & $\overline{\mathrm{X}}$ & Ss & $\mathrm{z}, \mathrm{t}$ & $\mathrm{p}$ \\
\hline \multirow{2}{*}{ Health Responsibility } & Sports Students & 97 & 8 & 32 & 19,62 & 5,077 & \multirow{2}{*}{$-4,430 * *$} & \multirow{2}{*}{, 000} \\
\hline & Pyschology Students & 102 & 9 & 26 & 16,56 & 3,979 & & \\
\hline \multirow{2}{*}{ Physical Activity } & Sports Students & 97 & 8 & 35 & 21,68 & 5,398 & \multirow{2}{*}{$-7,104 * *$} & \multirow{2}{*}{, 000} \\
\hline & Pyschology Students & 102 & 8 & 30 & 15,83 & 5,086 & & \\
\hline \multirow{2}{*}{ Nutrition, } & Sports Students & 97 & 8 & 30 & 18,23 & 4,814 & \multirow{2}{*}{$-2,830 * *$} & \multirow{2}{*}{,005 } \\
\hline & Pyschology Students & 102 & 8 & 33 & 16,30 & 4,332 & & \\
\hline \multirow{2}{*}{ İnterpersonal Relationships } & Sports Students & 97 & 9 & 35 & 26,11 & 4,566 & \multirow{2}{*}{,$- 689 * *$} & \multirow{2}{*}{,491 } \\
\hline & Pyschology Students & 102 & 16 & 34 & 25,85 & 4,135 & & \\
\hline \multirow{2}{*}{ Stress Management } & Sports Students & 97 & 11 & 32 & 20,02 & 4,376 & \multirow{2}{*}{$-2,381 * *$} & \multirow{2}{*}{, 017} \\
\hline & Pyschology Students & 102 & 11 & 37 & 18,79 & 3,849 & & \\
\hline \multirow{2}{*}{ Spritual Devolopment } & Sports Students & 97 & 14 & 32 & 23,86 & 4,569 & \multirow{2}{*}{$1,190^{*}$} & \multirow{2}{*}{,236 } \\
\hline & Pyschology Students & 102 & 9 & 32 & 23,12 & 4,180 & & \\
\hline \multirow{2}{*}{ Total } & Sports Students & 97 & 81 & 185 & 129,52 & 23,023 & \multirow{2}{*}{$4,465^{*}$} & \multirow{2}{*}{, 000} \\
\hline & Pyschology Students & 102 & 73 & 159 & 116,46 & 17,738 & & \\
\hline
\end{tabular}

When Table 2 is analyzed, a statistically significant difference was found between the Exercise and Sport Sciences Students and the Psychology Department students in terms of health responsibility, physical activity, nutrition and total scores in favor of the Department of Exercise and Sports Sciences $(p<0.05)$. As a result of the analyzes, no statistically significant difference was found between the groups in other sub-dimensions $(\mathrm{p}>0.05)$.

Table 3. Descriptive Statistics and P Values of the Subscales of Sub-Dimensions and Total Scores According to the Smoking Variable of the Participants's

\begin{tabular}{|c|c|c|c|c|c|c|c|c|}
\hline Sub-Dimensions & Smoking & $\mathrm{n}$ & Min. & Max. & $\overline{\mathrm{X}}$ & Ss & $\mathrm{z}$ & $\mathrm{p}$ \\
\hline \multirow[t]{2}{*}{ Health Responsibility } & Yes & 44 & 9 & 30 & 17,14 & 4,782 & \multirow{2}{*}{$-1,34$} & \multirow{2}{*}{, 176} \\
\hline & No & 155 & 8 & 32 & 18,31 & 4,774 & & \\
\hline \multirow[t]{2}{*}{ Physical Activity } & Yes & 44 & 8 & 30 & 18,36 & 6,232 & \multirow{2}{*}{,- 306} & \multirow{2}{*}{, 760} \\
\hline & No & 155 & 8 & 35 & 18,77 & 5,940 & & \\
\hline \multirow[t]{2}{*}{ Nutrition, } & Yes & 44 & 9 & 29 & 16,23 & 4,927 & \multirow{2}{*}{$-1,92$} & \multirow{2}{*}{, $046^{*}$} \\
\hline & No & 155 & 8 & 33 & 17,53 & 4,560 & & \\
\hline İnterpersonal & Yes & 44 & 9 & 32 & 22,57 & 5,110 & \multirow[b]{2}{*}{$-1,34$} & \multirow[b]{2}{*}{, 179} \\
\hline Relationships & No & 155 & 14 & 32 & 23,74 & 4,130 & & \\
\hline \multirow[t]{2}{*}{ Stress Management } & Yes & 44 & 16 & 33 & 25,20 & 4,491 & \multirow{2}{*}{$-1,33$} & \multirow{2}{*}{,182 } \\
\hline & No & 155 & 9 & 35 & 26,20 & 4,287 & & \\
\hline \multirow[t]{2}{*}{ Spritual Devolopment } & Yes & 44 & 11 & 25 & 18,30 & 4,152 & \multirow{2}{*}{$-1,65$} & \multirow{2}{*}{, 108} \\
\hline & No & 155 & 155 & 11 & 37 & 19,70 & & \\
\hline \multirow[t]{2}{*}{ Total } & Yes & 44 & 73 & 160 & 117,80 & 22,16 & \multirow{2}{*}{$-1,66$} & \multirow{2}{*}{,104 } \\
\hline & No & 155 & 80 & 185 & 124,25 & 21,18 & & \\
\hline
\end{tabular}

When the sub-dimensions and total scores of the scale according to the smoking variable of all participants were examined, the mean scores of the non-smokers in the nutrition sub-dimension were statistically higher than the participants who smoked ( $\mathrm{p}$ iç0.05). According to the analyzes, no significant difference was found between the 
groups in other sub-dimensions and in the total score $(\mathrm{p}>0.05)$.

\section{Discussion}

The life style that university students will pursue throughout their education will be the basis for a healthy life in the future. In these days when we have a pandemic process, increasing awareness about healthy lifestyle behaviors that have become more important has led to the necessity of a healthy and hygienic lifestyle in all areas. Pandemics such as COVID19 have shown that people's healthy lifestyles have a very important role in world health systems as well as providing healthcare services. The views of university students who have or will have important roles in providing health services and determining healthy lifestyles are also important. According to Maslow's "need hierarchy" theory, human tries to provide the most important needs in order of priority. These requirements are; Physical needs (food, water, sheltering...), Security needs (safety, protection, health...), Social needs (feeling of belonging to a community, love...), Need for respect (being respected in the community, social status ...) and Personal interests / are the requirements to reveal ideas / ideals. When it meets the needs at all levels, it goes to the next requirement (Malkoç N., 2019). In order to determine people's needs and needs, it is essential to have a healthy and medically good quality of life. This rule is valid for university students. Some studies have reported that the level of education is effective in performing health behaviors (Walker N 1988).

In addition, it is known that factors such as eating habits, sleep patterns and smoking will affect people's healthy lifestyles. In a study on housewives, perceptions of healthy lifestyle before and after Physical Activity were compared according to different variables (Socio-demographic status, Education, Number of children, Family type, Smoking, Marital Status, Weight) in terms of scale scores of the participants. As a result, statistical differences were found in some sub-dimensions of healthy lifestyle perceptions before and after physical activity according to family type, weight and marital status, which are different variables in terms of scale scores of the participants (Malkoç 2019). In our study, when the sub-dimensions and total scores of all participants were examined according to the variable of smoking and not smoking, a statistically significant difference was found in the nutrition sub-dimension in favor of non-smokers $(\mathrm{p}<0.05)$. No significant difference was found in other sub-dimensions and total score $(\mathrm{p}>0.05)$. This shows us that smoking has a negative effect on people's perception of nutrition in terms of healthy lifestyle. Today, the perspectives on lifestyle behaviors of the Psychology Department students who have been trained to meet their psychological health care needs and the Exercise and Sports Bilimero students who have determined their healthy lifestyle have gained importance.

According to the results of this study, the total score average of the students in Exercise and Sport Sciences was $129.52 \pm 23.023$, and the total score average of the students in the Department of Psychology was $116.46 \pm 17.738$ (Table 2). In addition, when the scores of the sub-dimensions of the scale were compared, the average pins of the Exercise and Sports Science Students were found to be higher and statistically significant compared to the other group ( $\mathrm{p}<0.05)$. This also contributes to the Healthy Lifestyle behavior behavior perceptions of Exercise and Sports Science students who are obliged to attend classes related to sports during the training process.

In the study conducted by Kaçan and Örsal (2019), it was aimed to determine the healthy lifestyle behaviors of the nursing students. When the average scores of the students obtained from the sub-dimensions of the scale were examined, they stated that the students got the highest score from the spiritual development and the lowest score from the physical activity sub-dimension.

The fact that the students of the nursing department had intensive theoretical course programs at the university and did not participate in any compulsory sports activities caused the scale to have the lowest score in the physical activity sub-dimension. According to the results of our study, the physical activity subscale scores of the psychology department students, who are related to health and have intensive theoretical course programs, were found to be low. This causes us to routinely apply exercise programs to students studying in departments with heavy and intensive theoretical curriculum. In terms of public health, sports and exercise lessons that will be placed in education programs that will enable students studying in these departments to lead a healthy lifestyle will be very useful.

In addition, Malkoç (2019) investigated the relationship between housewives 'perceptions of healthy living behavior and exercise, and concluded that exercise increased participants' perception of healthy living behavior. According to our results, the scale average scores of the Exercise and Sports Science students, even if they are required by their lessons, were higher than the students of the Department of Psychology.

In addition, their social appearance and related concerns are also very important in the university. In his research, Akkus (2019) has examined the Relationship Between Healthy Lifestyle Behaviors and Social Appearance Anxiety 
and concluded that there is a negative relationship between them. As the perception of healthy living behavior increases, people's social appearance anxiety levels decrease. University years, where the appearance is important for people, will have an important place in the future in terms of self-confidence. Appropriate sports and health education practices should be developed during the education process, as university students' activities and encouragement to develop healthy lifestyle behaviors will reduce their social appearance anxiety.

Koçoğlu and Akın (2009) stated in their study titled "The Relation of Socio-Economic Inequalities with Healthy Lifestyle Behaviors and Quality of Life", that even minor social differences have an impact on the perception of quality of life. In the same study, in the evaluation made for the summary scores of the physical and mental health components of the quality of life scale, women aged 54-65 (primary school graduates, those with a marital status, the place of birth and the place where the majority of their lives are villages, the number of individuals living in the household are 5-7 people. and the average number of rooms in the dwelling 2-3) is lower than the other groups.

When the relationship between monthly income physical and mental health summary scores was evaluated, statistically significant difference was found for all groups (Koçoğlu and Akın 2009). Considering that such factors are effective on the perception of healthy life, the levels of perception of healthy life of students studying in different departments may also differ. In our study, the Healthy Life Perception levels of the Department of Exercise and Sports Sciences and Psychology students who were subject to different education programs were found statistically significant in the direction of Exercise and Sports Science students $(\mathrm{p}<0.05)$.

Psychology Department Students who spend all their days in university life at university and who have intensive theoretical lesson programs and do not participate in any compulsory sports activities cannot participate in sports to improve their lifestyle and, accordingly, their Healthy Life Behavior Perceptions and, unfortunately, a lot of time and they cannot find any area. Apart from Exercise and Sport Sciences Students, many departmental students cannot attend any exercise program regularly for years. For this reason, students and departments with intensive curriculum, such as Psychology Science students, should be provided with the environment and opportunities to exercise regularly and improve their physical health. Arrangements should be made to enable them to engage in physical activities, such as elective courses that may differ from university routine and monotonous years. As a result of our study, it has been shown that Exercise and Sports Science students who do routine exercise in accordance with their curriculum have increased their perception of healthy life towards life. It is thought that university students who do regular sports will start to think that they are healthier and that individuals with whom they are in close contact can reflect this.

\section{References}

Akkuş Y., Türk R., \& Aydemir A. A. (2019). Evaluating the Relationship between Healthy Life Style Behaviours and Social Appearance Anxiety. Arc Health Sci Res, 6, 120-126. https://doi.org/10.17681/hsp.429806

Ayyildiz, E., Sunay, H., Kose, B., \& Atli, A. (2019). Investigation of the life quality of women in Ankara according to their participation in physical activity. Acta Medica Mediterranea, 35, 3427. https://doi.org/10.19193/0393-6384_2019_6_539

Bahar, Z., Beşer, A., Gördes, N., Ersin, F., \& Kıssal, A. (2008). Sağlıklı yaşam biçimi davranışları ölçeği II'nin geçerlik ve güvenirlik çalışması. Cumhuriyet Üniversitesi Hemşirelik Yüksekokulu Dergisi, 12(1), 1-13.

Cakırcalı, E. (2000). Hasta bakımı ve tedavisinde temel ilke ve uygulamalar. Güven \& Nobel Tıp Kitabevleri.

Chrysohoou, C., Angelis, A., Tsitsinakis, G., Spetsioti, S., Nasis, I., Tsiachris, D., \& Dimitris, T. (2015). Cardiovascular Effects Of High-İntensity İnterval Aerobic Training Combined With Strength Exercise İn Patients With Chronic Heart Failure. A Randomized Phase In Clinical Trial. International Journal of Cardiology, 179, 269-274. https://doi.org/10.1016/j.ijcard.2014.11.067

Conraads, V., Pattyn, N., De Maeyer, C., Beckers, P., Coeckelberghs, E., Cornelissen, V., ... Vanhees, L. (2015). Aerobic İnterval Training And Continuous Training Equally İmprove Aerobic Exercise Capacity İn Patients With Coronary Artery Disease: The Santex-Cad Study. International Journal of Cardiology [Int J Cardiol], 179, 203. https://doi.org/10.1016/j.ijcard.2014.10.155

Dimlioğlu, B., \& Tekin, M. (2018). Fiziksel Aktivitenin Orta Yaş Sedanter Kadınlarda Temel Psikolojik İhtiyaçlar Ve Öznel Iyi Oluş Düzeylerine Etkisininincelenmesi. Sosyal Bilimler Enstitüsü, Beden Eğitimi ve Spor Anabilim Dalı, Yükseklisans Tezi, Karamanoğlu Mehmetbey Üniversitesi, Karaman.

Duran Ü., Öğüt S., Asgarpour H., \& Kunter D. (2018). Evaluation of the Health Personnel's Healthy Lifestyle 
Behaviors. Journal of Adnan Menderes University Health Sciences Faculty, 2(3), 138-147.

Kaçan, C. Y., \& Örsal, Ö. (2019). Evaluation of Healthy Life Style Behaviors Level of Nursing Students. $J$ DU Health Sci Inst., 9(1), 19-24.

Koçoğlu, D., \& Akın, B. (2009). Sosyoekonomik Eşitsizliklerin Sağlıklı Yaşam Biçimi Davranışları ve Yaşam Kalitesi ile İlişkisi. Dokuz Eylül Üniversitesi Hemşirelik Yüksekokulu Elektronik Dergisi, 2(4), 145-154.

Lim, K., \& Taylor, L. (2005) Factors Associated With Physical Activity Among Older People A Population-Based Study. Preventive Medicine, 40(1), 33-40. https://doi.org/10.1016/j.ypmed.2004.04.046

Malkoç N. (2019). Kocaeli Anne Şehir" Projesine Katılan Annelere Uygulanan Fiziksel Aktivitelerin Sağllkl Yaşam Davranışlarına Etkisinin Araştırılması (Kocaeli İli Örneği). Kocaeli Üniversitesi, Y. Lisans Tezi.

Sisk, R. J. (2000). Caregiver burden and health promotion. International Journal of Nursing Studies, 37(1), 37-43. https://doi.org/10.1016/s0020-7489(99)00053

Sunay, H., Uyar, Y., Bal, E., \& Ayyıldız, E. (2020). Analysis of Trainers's Wellness in Turkey. Acta Medica Mediterranea, 36, 2371. https://doi.org/10.19193/0393-6384_2020_4_368

Turğut, M., \& Yaşar, O. (2019). Psychological Help Attitude and Sports. Iğdır University Sport Science Journal, 2(1), 1-15.

Walker, N., Volkan, K., \& Sechrist, K. (1988). Health promoting life styles of older adults: Comparisons with young and middle - aged adults, correlates and patterns. Adv Nurs Sci, 11(1), 76-90. https://doi.org/10.1097/00012272-198810000-00008

Walker, S., Sechrist, K., \& Pender, N. J. (1987). The Health Promoting Lifestyle Profile Development and $\begin{array}{lllll}\text { Psychometric Characteristics. } & \text { Nursing }\end{array}$ https://doi.org/10.1097/00006199-198703000-00002

Yasar, O. M., \& Turgut, M. (2020). Financial Situation of College Students. World Journal of Education, 10(1), 42-48. https://doi.org/10.5430/wje.v10n1p42

Zorba, E. (2015). Fiziksel Aktivite Ve Fiziksel Uygunluk. Gazi Kitapevi.

\section{Copyrights}

Copyright for this article is retained by the author(s), with first publication rights granted to the journal.

This is an open-access article distributed under the terms and conditions of the Creative Commons Attribution license (http://creativecommons.org/licenses/by/4.0/). 